\title{
Histocompatibility antigens in psoriasis, psoriatic arthropathy, and ankylosing spondylitis
}

\author{
R. D. ARMSTRONG, G. S. PANAYI, AND K. I. WELSH* \\ From the Departments of Medicine and Rheumatology and the *Tissue Typing Laboratory, Guy's Hospital, \\ London SE1 9RT
}

SUMMARY Patients with ankylosing spondylitis, psoriatic arthritis, and psoriasis alone were typed for HLA A, B, Cw, and DR antigens, and the antigen frequencies were compared with those in a normal control population and in patients with rheumatoid arthritis. Patients with psoriasis had a significantly raised frequency of Cw6. Those with arthritis in addition to their psoriasis also had raised frequencies of B27 and DR7. Patients with ankylosing spondylitis were characterised by the expected high frequency of HLA B27. Again, those with peripheral arthritis had a higher B27 and DR7 frequency than those without. DR3 is associated with the development of erosions in psoriatic arthritis.

The major histocompatibility complex (MHC) on human chromosome 6 codes for a variety of products whose common feature is an intimate involvement in the immune response. Genes determining HLA antigens form an important part of the MHC and have attrăcted considerable attention because of the association between certain antigens and a variety of diseases. ${ }^{1}$ In particular, various arthropathies are linked to products of the MHC, the strongest known association being that between HLA B27 and ankylosing spondylitis (AS). ${ }^{23}$ There was initial disappointment at not finding an association between rheumatoid arthritis and an HLA A or B antigen, but 2 groups later simultaneously described an association with HLA DR4. ${ }^{45}$ The link between a disease and a given HLA antigen is not absolute, however. Not all patients possess the antigen, and only a minority of individuals with the antigen will develop the disease. This has led to speculation that a closely linked gene may predispose to development of the disease, perhaps through determining a particular type of immune response to an environmental agent. The phenomenon of linkage disequilibrium provides some theoretical support for this idea.

Psoriatic arthropathy (PsA) and ankylosing spondylitis are often included with other arthropathies such as Reiter's syndrome and reactive arthritis under the umbrella term 'seronegative spondarthritides'. This terminology acknowledges

Accepted for publication 19 February 1982.

Correspondence to Professor G. S. Panayi. similarities between these conditions but disguises lack of knowledge about their aetiology. Many groups have confirmed an increased prevalence of HLA B27 in psoriatic arthritis, ${ }^{6-10}$ which reflects the frequent occurrence of sacroiliitis and spondylitis in these patients. However, various differences in other HLA antigens have also been reported. For instance, in psoriasis with or without arthritis there is an increase in frequency of $\mathrm{A} 1, \mathrm{~B} 13, \mathrm{~B} 17$, and Cw6, ${ }^{7-9}{ }^{11-15}$ while patients with arthritis are reported to show an increase in frequency of A26 and B38. ${ }^{16-18}$ With regard to HLA DR antigens, Murray et al. ${ }^{18}$ have recently reported finding a significant increase of DR7 in patients with psoriasis and of DR4 in those with arthritis. This finding may imply some similarity in pathogenesis between rheumatoid arthritis and psoriatic arthritis.

HLA DR typing has not been pursued with great vigour in cases of ankylosing spondylitis, primarily because the association with HLA B27 is so strong. Results have indicated either no association ${ }^{19}$ or, in one report, a reduction in HLA DR1 and DR7 in patients with AS. ${ }^{20}$ In view of the reported increase in DR4 in psoriatic patients with arthritis we wondered whether a similar increase might be detected in AS patients with peripheral arthritis.

\section{Patients and methods}

Patients were selected at random from those attending the Departments of Rheumatology and Der142 
matology at Guy's Hospital. The groups consisted of unrelated Caucasian patients with psoriasis alone (30), psoriatic arthritis (24), and ankylosing spondylitis (33). The patients with psoriatic arthritis were seronegative for rheumatoid factor and fulfilled the diagnostic criteria of Moll and Wright. ${ }^{21}$ Patients with psoriasis alone were questioned about rheumatic symptoms, and those giving any history of arthralgia or arthritis were excluded from the study. Patients with ankylosing spondylitis were subdivided into those with and those without peripheral arthritis. Patients with hip or shoulder involvement only were included in the group without peripheral arthritis. Various details of clinical information were recorded, including age at onset and family history.

HLA TYPING

HLA A, B, Cw, and DR typing was carried out with 8th Histocompatibility Workshop Standardised Sera and by previously described methods. ${ }^{22}$ HLA types of 153 normal individuals and 178 patients with rheumatoid arthritis were available for comparison. Only the psoriatic patients were typed for $\mathrm{Cw}$ antigens.

Statistical analysis was by the chi-square test with Yates's correction.

\section{Results}

HLA antigen frequencies of the patients with psoriasis are shown in Table 1 . The most striking feature is the very high prevalence of Cw6 in all psoriatic patients (chi-square 48.5, $\mathrm{p}<0.001$ ). This over-shadows all other changes in HLA frequency, and there is no significant difference with respect to this antigen between patients with and without arthritis, though it is higher in the latter group. Antigens showing a significant increase in all patients with psoriasis were A1 $(\mathrm{p}<0.001), \mathrm{B} 13(\mathrm{p}<0.01)$, and B17 $(p<0.001)$, while $B 12$ was significantly decreased $(p<0 \cdot 001)$. Those antigens showing a significant increase in only those patients with arthritis were B27 $(\mathrm{p}<0 \cdot 01)$ and DR7 $(\mathrm{p}<0 \cdot 05)$. HLA Aw30 was increased in patients without arthritis, and the frequency of A10 was not significantly altered. The frequency of HLA DR4 was not raised in the group with arthritis.

In Table 2 are shown similar details for patients with ankylosing spondylitis. The expected very high prevalence of B27 was observed $(81.8 \%$ overall). Also significantly increased were DR1 and DR2 $(p<0 \cdot 05)$. There was no significant difference between the subgroups with and without peripheral arthritis, though A1 was significantly lower in those with peripheral arthritis than in normal controls $(\mathrm{p}<0.05)$. In this subgroup DR3 was much lower $(5.6 \%)$ than in normal persons $(28.4 \%)$, but the difference did not achieve statistical significance. B27 and DR7 occurred more frequently in those with peripheral arthritis than in those without.

Table 1 HLA antigen frequencies (percentages) in psoriatic patients with and without arthritis compared with those in controls. Values for $D R$ antigen frequencies and those $A, B$, and $C w$ antigens showing alteration are included. The numbers in brackets refer to the number of patients tested

\begin{tabular}{|c|c|c|c|c|c|c|}
\hline \multirow[t]{2}{*}{$H L A$ antigens } & \multirow{2}{*}{$\begin{array}{l}\text { Normal controls } \\
\text { (153) }\end{array}$} & \multicolumn{3}{|l|}{ Psoriasis } & \multirow[t]{2}{*}{ Chi-square } & \multirow[t]{2}{*}{$p$ value } \\
\hline & & Total (54) & With arthritis (24) & No arthritis (30) & & \\
\hline $\begin{array}{l}\text { A1 } \\
\text { A10 } \\
\text { A28 } \\
\text { AW30 } \\
\text { B12 } \\
\text { B13 } \\
\text { B17 } \\
\text { B27 }\end{array}$ & $\begin{array}{r}22.8 \\
11 \cdot 8 \\
11.8 \\
5.9 \\
36.6 \\
2.0 \\
6.5 \\
11.8\end{array}$ & $\begin{array}{l}55 \cdot 6^{*} \\
13 \\
1 \cdot 9 \\
13 \\
13^{*} \\
13^{*} \\
33 \cdot 3^{*} \\
20 \cdot 4\end{array}$ & $\begin{array}{l}50 \\
12 \cdot 5 \\
0 \\
4 \cdot 2 \\
12 \cdot 5 \\
8 \cdot 4 \\
29 \cdot 2 \\
37 \cdot 5^{*}\end{array}$ & $\begin{array}{l}60 \\
13 \cdot 3 \\
3 \cdot 3 \\
20^{*} \\
13 \cdot 3 \\
16 \cdot 7 \\
36 \cdot 7 \\
6 \cdot 7\end{array}$ & $\begin{array}{r}19 \cdot 2 \\
3 \cdot 6 \\
9 \cdot 5 \\
8 \cdot 7 \\
22 \cdot 3 \\
8 \cdot 7\end{array}$ & $\begin{array}{l}<0.001 \\
\text { NS } \\
<0.01 \\
<0.001 \\
<0.01 \\
<0.001 \\
<0.01\end{array}$ \\
\hline $\begin{array}{l}\text { Cw4 } \\
\text { Cw6 }\end{array}$ & $\begin{array}{l}(148) \\
22.3 \\
20.9\end{array}$ & $\begin{array}{c}(46) \\
8 \cdot 7 \\
78 \cdot 3^{*}\end{array}$ & $\begin{array}{r}(21) \\
4 \cdot 8 \\
71 \cdot 4\end{array}$ & $\begin{array}{l}(25) \\
12 \\
84\end{array}$ & $48 \cdot 5$ & $<0.001$ \\
\hline $\begin{array}{l}\text { DR1 } \\
\text { DR2 } \\
\text { DR3 } \\
\text { DR4 } \\
\text { DR5 } \\
\text { DR6 } \\
\text { DR7 }\end{array}$ & $\begin{array}{l}(148) \\
14.9 \\
21 \cdot 6 \\
28 \cdot 4 \\
33 \cdot 8 \\
14.9 \\
17 \cdot 7 \\
26 \cdot 8\end{array}$ & $\begin{array}{l}(54) \\
22 \cdot 2 \\
22 \cdot 2 \\
24 \cdot 1 \\
22 \cdot 2 \\
22 \cdot 2 \\
20 \cdot 4 \\
38 \cdot 9\end{array}$ & $\begin{array}{l}(24) \\
20 \cdot 8 \\
25 \\
25 \\
20 \cdot 8 \\
12 \cdot 5 \\
8 \cdot 4 \\
50^{*}\end{array}$ & $\begin{array}{l}(30) \\
23 \cdot 3 \\
20 \\
23 \cdot 3 \\
23 \cdot 3 \\
30 \\
30 \\
30\end{array}$ & $4 \cdot 1$ & $<0.05$ \\
\hline
\end{tabular}

* Significantly different from normal controls.

NS = not significant. 
Table 2 HLA antigen frequencies (percentages) in patients with ankylosing spondylitis with and without peripheral arthritis compared with those in normal controls. Values for DR antigen frequencies and those $A$ and $B$ antigens showing changes are included

\begin{tabular}{|c|c|c|c|c|c|}
\hline \multirow[t]{2}{*}{ HLA antigens } & \multirow[t]{2}{*}{ Normal controls (153) } & \multicolumn{3}{|c|}{ Ankylosing spondylitis } & \multirow[t]{2}{*}{$p$ value } \\
\hline & & Total (33) & $\begin{array}{l}\text { With peripheral } \\
\text { arthritis (18) }\end{array}$ & $\begin{array}{l}\text { Without peripheral } \\
\text { arthritis (15) }\end{array}$ & \\
\hline $\begin{array}{l}\text { A1 } \\
\text { B12 } \\
\text { B17 } \\
\text { B27 }\end{array}$ & $\begin{array}{r}22 \cdot 8 \\
36 \cdot 6 \\
6 \cdot 5 \\
11 \cdot 8\end{array}$ & $\begin{array}{c}15 \cdot 2 \\
21 \cdot 2 \\
3 \cdot 0 \\
81 \cdot 8^{*}\end{array}$ & $\begin{array}{l}5 \cdot 6^{*} \\
11 \cdot 1 \\
0 \\
88 \cdot 9\end{array}$ & $\begin{array}{r}26 \cdot 7 \\
33 \cdot 3 \\
6 \cdot 7 \\
73 \cdot 3\end{array}$ & $<0.05$ \\
\hline $\begin{array}{l}\text { DR1 } \\
\text { DR2 } \\
\text { DR3 } \\
\text { DR4 } \\
\text { DR5 } \\
\text { DR6 } \\
\text { DR7 }\end{array}$ & $\begin{array}{l}(148) \\
14 \cdot 9 \\
21 \cdot 6 \\
28 \cdot 4 \\
33 \cdot 8 \\
14 \cdot 9 \\
17 \cdot 7 \\
26 \cdot 8\end{array}$ & $\begin{array}{l}(33) \\
48 \cdot 5^{*} \\
42 \cdot 4^{*} \\
18 \cdot 2 \\
27 \cdot 3 \\
9 \cdot 1 \\
12 \cdot 1 \\
21 \cdot 2\end{array}$ & $\begin{array}{l}(18) \\
50 \\
44 \cdot 4 \\
5 \cdot 6 \\
22 \cdot 2 \\
11 \cdot 1 \\
16 \cdot 7 \\
27 \cdot 8\end{array}$ & $\begin{array}{l}(15) \\
46 \cdot 7 \\
40 \\
33 \cdot 3 \\
33 \cdot 3 \\
6 \cdot 7 \\
6 \cdot 7 \\
13 \cdot 2\end{array}$ & $\begin{array}{l}<0.05 \\
<0.05 \\
\text { NS } \\
\text { NS }\end{array}$ \\
\hline
\end{tabular}

*Significantly different from normal controls.

Table 3 Comparison between patients with psoriatic arthritis, ankylosing spondylitis, and rheumatoid arthritis in terms of alterations in frequency of certain HLA antigens

\begin{tabular}{|c|c|c|c|c|}
\hline $\begin{array}{l}H L A \\
\text { antigens }\end{array}$ & $\begin{array}{l}\text { Normal } \\
\text { controls } \\
\text { (153) }\end{array}$ & $\begin{array}{l}\text { Psoriatic } \\
\text { arthritis } \\
\text { (24) }\end{array}$ & $\begin{array}{l}\text { Ankylosing } \\
\text { spondylitis } \\
\text { (33) }\end{array}$ & $\begin{array}{l}\text { Rheumatoid } \\
\text { arthritis } \\
\text { (178) }\end{array}$ \\
\hline A1 & $22 \cdot 8$ & 50 & $15 \cdot 2$ & 44.9 \\
\hline B8 & $22 \cdot 2$ & 25 & $12 \cdot 1$ & 38.8 \\
\hline B12 & $36 \cdot 6$ & $12 \cdot 5$ & $21 \cdot 2$ & $26 \cdot 4$ \\
\hline B13 & $2 \cdot 0$ & $8 \cdot 4$ & 3.0 & $2 \cdot 8$ \\
\hline B17 & $6 \cdot 5$ & $29 \cdot 2$ & $3 \cdot 0$ & $5 \cdot 6$ \\
\hline \multirow{2}{*}{ B27 } & $11 \cdot 8$ & $37 \cdot 5$ & $81 \cdot 8$ & $11 \cdot 8$ \\
\hline & (148) & (24) & (33) & $(178)$ \\
\hline DR1 & 14.9 & $20 \cdot 8$ & $48 \cdot 5$ & $14 \cdot 6$ \\
\hline DR2 & $21 \cdot 6$ & 25 & $42 \cdot 4$ & 14 \\
\hline DR3 & $28 \cdot 4$ & 25 & $18 \cdot 2$ & $31 \cdot 5$ \\
\hline DR4 & 33.8 & $20 \cdot 8$ & $27 \cdot 3$ & $58 \cdot 4$ \\
\hline DR5 & 14.9 & $12 \cdot 5$ & $9 \cdot 1$ & $7 \cdot 3$ \\
\hline DR6 & $17 \cdot 7$ & 8.4 & $12 \cdot 1$ & $9 \cdot 0$ \\
\hline DR7 & $26 \cdot 8$ & 50 & $21 \cdot 2$ & $20 \cdot 8$ \\
\hline
\end{tabular}

Table 4 Selected HLA antigens in patients with psoriatic arthritis with and without joint erosions or sacroiliitis

\begin{tabular}{lcllll}
\hline & Total & B27 & DR3 & DR4 & DR7 \\
\hline Erosions & 15 & 6 & 6 & 2 & 8 \\
No erosions & 9 & 3 & 0 & 3 & 4 \\
\hline Sacroiliitis & 12 & 6 & 4 & 4 & 4 \\
No sacroiliitis & 12 & 3 & 2 & 2 & 8 \\
\hline
\end{tabular}

In Table 3 we show comparative figures for patients with psoriatic arthritis, ankylosing spondylitis, rheumatoid arthritis, and normal individuals. In psoriatic and rheumatoid arthritis there is an increase in $\mathrm{A} 1$, and in the latter group this is in association with B8, these 2 HLA antigens being in linkage disequilibrium. Although all groups share some reduction in B12, this is significant only in patients with psoriatic arthritis.

Analysis of clinical details of the groups of patients yielded little additional information, but there was a striking difference between patients with and without erosions in the psoriatic group (Table 4). Six of the 15 patients with erosions possessed HLA DR3 in contrast to none of 9 without erosions. This was not statistically significant because of the small numbers available for analysis. Also shown are the numbers with and without sacroiliitis. As might be expected, more of those with sacroiliitis than without it were B27-positive. As regards the numbers in these groups with DR4 and DR7, no trend was observed.

When HLA antigens were analysed with respect to other clinical details, such as age at onset and family history, no major trends in frequency of HLA antigens were observed.

\section{Discussion}

Many reports describe an association between HLA antigens and psoriasis and psoriatic arthropathy. Most workers are agreed on a significant increase in frequency of HLA B13 and B17. ${ }^{7-9111215}$ Several reports also mention an increase in $\mathrm{A} 1$ and DR7, ${ }^{9121518}$ and although B12 is low in some studies $^{17}{ }^{23}$ this only achieves statistical significance in one report. ${ }^{23}$ However, this result later lost its significance when the number of patients was enlarged. ${ }^{24}$ In view of the strong association between the HLA antigen Cw6 and psoriasis ${ }^{12-15}$ it is perhaps surprising that not more attention has been paid to this antigen. Our patients appeared to be similar to others in their 
increased possession of $\mathrm{A} 1, \mathrm{~B} 13$, and $\mathrm{B} 17$ and the decrease in B12.

More striking was the increase in Cw6. A report from the 8th Histocompatibility Workshop ${ }^{15}$ described a significant association between psoriasis and DR7 and posed the question whether the primary association of the disease is with Cw6 or DR7. Our results indicate very strongly that the primary association of psoriasis is with Cw6. Of the 25 patients without psoriatic arthritis who were $\mathrm{Cw}$ locus typed, 21 were Cw6-positive but only 8 had DR7. The HLA B27 frequency was lowered in this group, and the rise of A1, B13, and B17 could all be ascribed to the high Cw6 frequency. In those psoriatic patients with arthritis DR7, Cw6, and B27 were significantly raised. These patients' results are very similar to those reported for Caucasoid patients in the 8th Workshop Study, ${ }^{15}$ and in that report the majority were English and appear to have had arthritis. Thus, our results indicate that Cw6 is the primary association with psoriasis and that DR7 is an additional marker for psoriatic arthritis.

If we assume this to be so, then from the known linkage disequilibrium between Cw6 and A locus antigens $^{25}$ we would expect $\mathrm{A} 1$ and $\mathrm{AW} 30$ to be raised and A3, A9, A10, and A28 to be lowered. This is almost what happens with the exception of $A 10$ (A26 is a 'split' of A10), which is increased slightly but not significantly (other results not shown). This is in keeping with other reports. ${ }^{16}{ }^{18}$ In the B series we would also assume B13 and B37 to be raised and B7, $\mathrm{B} 8, \mathrm{~B} 12$, and $\mathrm{B} 27$ to be lowered. In practice $\mathrm{B} 13$ but not B37 is raised and B12 is very significantly lowered. HLA B27 is indeed lowered in the psoriasisalone group. In the patients with psoriatic arthritis B27 but not DR4 is raised, suggesting that their peripheral arthritis is more akin to that in other forms of seronegative spondarthritis than to rheumatoid arthritis.

One other HLA association is of particular note. Of the psoriatic arthritis patients with erosions (15) 6 had DR3 while none of the 9 without erosions possessed this antigen.

As mentioned previously, our results are very similar to those of the 8th Histocompatibility Workshop report ${ }^{15}$ but differ considerably in some respects from those of Murray et al. ${ }^{18} \mathrm{~A}$ number of reasons for this are possible. For instance, Murray et al. included a number of patients of Jewish origin, while our series had none, so that ethnic variations may contribute. Their figures for antigen frequencies in normal individuals also diverge considerably from ours in some cases. To quote one example, for DR6 they found a frequency of $34.9 \%$ while in our series it was $17.7 \%$. For these reasons it is unjustifiable to compare our results with theirs.
In our patients with ankylosing spondylitis the association with HLA B27 was confirmed. Interestingly, in those with peripheral arthritis A1 was significantly decreased, in sharp contrast to those with psoriatic arthritis. In addition the frequency of DR3 was very low in those with peripheral arthritis, but HLA DR4 was not increased. However, B27 and DR7 were higher in those patients with peripheral arthritis, showing some parallel with psoriatic arthritis.

The significance of such alterations in histocompatibility antigens in these conditions is as yet a matter for speculation. Our findings argue against the idea that DR4 is a nonspecific marker for peripheral arthritis and suggest that it is fairly specific for RA. In ankylosing spondylitis opinion is sharply divided as to whether the B27 antigen itself is crucial to the disease process-for example, by 'molecular mimicry'26 - or whether it is simply in close linkage disequilibrium with a separate disease susceptibility gene. Many workers believe that 'immune response' genes may predispose to disease in suceptible individuals. However, this is at present little more than a theory, and it is probable that many factors may converge to result in the disease process. In psoriasis and psoriatic arthropathy, as suggested by Murray et al., ${ }^{18}$ development of disease is probably under polygenic control. For example, Cw6 seems to be the primary predisposing factor for psoriasis, while other antigens such as B27 and DR7 may further predispose the individual to develop arthritis.

Although the MHC is intimately involved in the regulation of the immune response, it may be misleading to view the association between HLA antigens and all diseases purely in these terms. For example, haemochromatosis, a 'purely' metabolic disorder, is associated with possession of HLA A3. Psoriasis itself, although of unknown aetiology, is characterised by apparently disordered control of cell turnover in the epidermis. This does not appear at first glance to be a primarily immunological phenomenon.

We are most grateful to Dr R. S. Wells, Dr D. M. MacDonald, Dr R. Grahame, and Dr T. Gibson for permission to study patients under their care. R. D. Armstrong was supported by an Arthritis and Rheumatism Council fellowship. The expert technical help of Lesley Kennedy, David Briggs, and Bob Vaughan made this study possible, as did financial support from the Guy's Hospital Trustees.

\section{References}

1 Bodmer W F. The HLA system and disease. Oliver Sharpey Lecture 1979. J R. Coll Physicians Lond 1980; 14: 43-50.

2 Brewerton D A, Caffrey M, Hart F D, James D C O, Nicholls A, Sturrock R D. Ankylosing spondylitis and HLA 27. Lancet 1973; i: 904-7.

3 Schlosstein L, Terasaki P I, Bluestone R, Pearson C M. High association of an HLA antigen, W27, with ankylosing spondylitis. N Engl J Med 1973; 288: 704-6. 


\section{Armstrong, Panayi, Welsh}

4 Stastny P. Association of the B-cell alloantigen DRW4 with rheumatoid arthritis. $N$ Engl J Med 1978; 298: 869-71.

5 Panayi G S, Wooley P, Batchelor J R. Genetic basis of rheumatoid disease: HLA antigens, disease manifestations, and toxic reactions to drugs. $\mathrm{Br} \mathrm{Med} \mathrm{J} \mathrm{1978;} \mathrm{ii:} \mathrm{1326-8.}$

6 Brewerton D A, Caffrey M, Nicholls A, Walters D, James D C O. HLA-B27 and arthropathies associated with ulcerative colitis and psoriasis. Lancet 1974; i: 956-7.

7 Karvonen J, Lassus A, Sievers V, Tiilikainen A. HL-A antigens in psoriatic arthritis. Ann Clin Res 1974; 6: 304-7.

8 McClusky O E, Lordon R E, Arnett F C. HL-A27 in Reiter's syndrome and psoriatic arthritis; a genetic factor in disease susceptibility and expression. $J$ Rheumatol $1974 ; 1: 263-8$.

9 Metzger A L, Morris R I, Bluestone R, Terasaki P I. HL-A W27 in psoriatic arthropathy. Arthritis Rheum 1975; 18: 111-5.

10 Lambert J R, Ansell B M, Stephenson E, Wright V. Psoriatic arthritis in childhood. Clin Rheum Dis 1976; 2: 339-52.

11 Green L, Meyers O L, Gordon W, Briggs B. Arthritis in psoriasis. Ann Rheum Dis 1981; 40: 366-9.

12 Tsuji K, Inouye H, Nose Y, Sasazuki T, Ozawa A, Ohkido M. Further studies in HLA A B C D DR and haptotype antigen frequencies in psoriasis vulgaris. Acta Derm Venereol (Stockh) 1979; 59: suppl 87: 107-8.

13 Tiilikainen A, Lassus A, Karvonen J, Vartainen P, Julin M. Psoriasis and HLA Cw6. Br J Dermatol 1980; 102: 179-84.

14 Batchelor J R, Morris P J. HLA and disease-joint report. In: Bodmer W F, Batchelor J R, Bodmer J G, Festenstein H, Morris P J, eds. Histocompatibility Testing, 1977. Copenhagen: Munksgaard, 1978: 205.

15 Hawkins B R, Tiwari J L, Lowe N, et al. HLA and psoriasis. In:
Terasaki P I, ed. Histocompatibility Testing, 1980. Los Angeles: UCLA Tissue Typing Laboratory, 1981: 711-4.

16 Roux H, Mercier P, Maestracci D, et al. Psoriatic arthritis and HLA antigens. J Rheumatol 1977; 4: 64-5.

17 Espinoza L R, Vasey F B, Oh J M, Wilkinson R, Osterland C K. Association between HLA-B38 and peripheral psoriatic arthritis. Arthritis Rheum 1978; 21: 72-5.

18 Murray C, Mann D L, Gerber L N, et al. Histocompatibility alloantigens in psoriasis and psoriatic arthritis. Evidence for the influence of multiple genes in the major histocompatibility complex. J Clin Invest 1980; 66: 670-5.

19 Kemple K, Gatti R A, Leibold W, Klinenberg J, Bluestone R. HLA-D locus typing in ankylosing spondylitis and Reiter's syndrome. Arthritis Rheum 1979; 22: 371-5.

20 Dejelo C L, Braun W E, Khan M A, Clough J D. HLA-DR antigens and ankylosing spondylitis. Transplant Proc 1978; 10: 971-2.

21 Moll J M H, Wright V. Psoriatic arthritis. Semin Arthritis Rheum 1973; 3: 55-78.

22 Welsh K I, Batchelor J R, Weir D M. Handbook of Experimental Immunology. Oxford: Blackwell, 1978: 315-352.

23 White H S, Newcomer V D, Mickey M R, Terasaki P I. Disturbance of HL-A antigen frequency in psoriasis. $N$ Engl J Med 1972; 287: 740-3.

24 Krain L S, Newcomer V D, Terasaki P I. HLA antigens in psoriasis. N Engl J Med 1973; 288: 1245 (abstr).

25 Terasaki P I. Histocompatibility Testing 1980. Los Angeles: UCLA Tissue Typing Laboratory, 1981.

26 Editorial. Klebsiella and ankylosing spondylitis-molecular mimicry? Lancet 1979; i: 1012-3. 